\title{
Online Alışveriş Yapan Süpermarket Tüketicilerinin TüketimTercihlerinin Teknoloji Kabul Modeliyle Açıklanması
}

\author{
DOI: $10.26466 /$ opus.837561
}

$*$

\author{
Perihan Ișik* - Murat ÖZ $z^{* *}$ \\ * Dr. Öğr., Nevşehir Hacı Bektaş Veli Üniversitesi, SBE, Nevşehir/Türkiye \\ E-Posta: perihan4233@gmail.com \\ ORCID: $\underline{\text { 0000-0003-0088-2595 }}$ \\ **Doç.Dr. Karamanoğlu MehmetBey Üniversitesi, İ̈BF, Karaman/ Türkiye \\ E-Posta: $\underline{\text { muratoz@kmu.edu.tr }}$ \\ ORCID: $\quad \underline{0000-0003-4955-3848}$
}

Öz

Günümüzde internette yaşanan gelişmeler her geçen gün artmaktadır. Bilgi ve iletişim teknolojisinde yaşanan gelişmeler, internet olgusunun hayatımızda vazgeçilmez bir unsur olmasına neden olmuştur. Hayatımızın en önemli parçalarından biri haline gelen internet, birçok tüketiciyi online alışverişe yönlendirmiştir. Online alışveriş sayesinde insanlar fiziksel bir alışveriş mağazasına gitmeden, oturdukları yerden istek ve ihtiyaçlarını karşılama imkânına sahiptirler. Bu çalışmanın amacı online (çevrimiçi) alışveriş yapan süpermarket tüketicilerinin, tüketim tercihlerini etkileyen faktörleri, teknoloji kabul modeli (TKM) ile açıklamaktır. Bu amaç doğrultusunda çalışmada TKM'nin ana değişkenleri (algılanan fayda, algılanan kullanım kolaylı̆̆ı, tutum ve niyet) ile online alışveriş davranışını etkileyen (güven, gizlilik ve alışveriş keyfi) değişkenler arasındaki ilişkiler irdelenmeye çalışılmıştır. Çalışmanın ana kütlesini Türkiye'de yaşayan, süpermarketlerden en az bir kez online alışveriş yaptığı tespit edilen süpermarket tüketicileri oluşturmaktadır. Veriler anket formu ile toplanmıştır. Toplanan veriler SPSS 21 paket programı ile analiz edilmiştir. Ölçeğin geçerliliği ve güvenirliliğini tespit etmek amacıyla faktör analizi uygulanmış ve analiz sonucunda toplamda yedi faktör belirlenmiştir. Araştırma verilerinin çözümlenmesinde korelasyon katsayısı analizi ve basit doğrusal regresyon analizi yöntemleri kullanılmıştır. Analiz sonucunda güven, gizlilik ve alışveriş keyfi değişkenlerinin TKM'nin ana değişkenlerini oluşturan algılanan fayda, algılanan kullanım kolaylığı, tutum ve niyet üzerinde etkisi olduğu sonucuna ulaşılmıştır $(p=, 000<0,05)$.

Anahtar Kelimeler: Online alışveriş, teknoloji kabul modeli, satın alma davranışı. 
ISSN:2528-9527

E-ISSN: 2528-9535

Yıl Year. 11

Cilt Volume: 18

Sayı Issue: Yönetim ve Organizasyon Özel Sayısı

Temmuz July 2021

\title{
Explanation of the Consumption Preferences of Supermarket Consumers Making Online Shopping with Technology Acceptance Model
}

\begin{abstract}
Today, the developments in the internet are increasing day by day. Internet phenomenon has become an indispensable element in our lives owing to the developments in information and communication technology. Internet, which has become an important part of our lives, has led many consumers to online shopping. Thanks to online shopping, consumers have the opportunity to meet their wants and needs from where they sit, without going to a physical store. The purpose of this study is to explain the consumer preferences of the supermarket consumers who shop online with the technology acceptance model (TAM). The relationships between the main variables (perceived utility, perceived ease of use, attitude and intention) and the variables that affect online shopping behavior (trust, privacy and shopping pleasure) were examined. Consumers that apply at least once online shopping from the supermarket constitute the population of the study. The data were collected with a questionnare. Collected data were analyzed with SPSS 21 package program. Factor analysis was applied to determine the validity and reliability of the scale and a total of seven factors were determined. Correlation coefficient analysis and simple linear regression analysis methods were applied and the results indicate that trust, privacy and shopping pleasure have effects on perceived utility, perceived ease of use, attitude and intention ( $p=000<0.05)$.
\end{abstract}

Keywords: Online shopping, technology acceptance model, purchasing behavior. 


\section{Giriş}

Geçmişten günümüze kadar gerek küreselleşmenin artması gerekse de bilgi ve iletişim teknolojilerinde yaşanan gelişmeler internet olgusunu hayatımızın bir parçası haline getirmiştir. Hayatımızın vazgeçilmez bir unsuru olan internet; sayısız bilgisayarı birbirine bağlayan ve sürekli olarak gelişen ve yaygınlaşan iletişim ağlarından birisidir. Bireyler internet sayesinde birçok bilgiye kolaylıkla ulaşabilmekte ve paylaşabilmektedir.

Gün geçtikçe kullanıcı sayısı artan internetin, kullanım amaçları da çeşitlenmektedir (Akman ve Işık, 2018, s.21). Günümüzde gerek işletmeler gerekse tüketiciler farklı amaçlarla interneti yoğun bir şekilde kullanmaktadır (Gül ve Boz, 2012, s.6). İşletmeler için internet, pazarlamaya yönelik faaliyetlerin yürütüldüğü en önemli mecralardan birisidir (Kaş, 2015, s.1). Birçok işletme internet sayesinde coğrafi sınırları ortadan kaldırarak müşterilerle iletişim kurmakta ve müşterilere kolaylıkla ulaşabilmektedir (Agcadağ, 2014, s.21).

$\mathrm{Bu}$ çalışmanın amacı online (çevrimiçi) alışveriş yapan süpermarket tüketicilerinin tüketim tercihlerini etkileyen faktörleri TKM ile açıklamaktır. Bu amaç doğrultusunda TKM'nin ana değişkenleri olan algılanan fayda, algılanan kullanım kolaylığı, tutum ve niyet değişkenleri ve bu değişkenler üzerinde etkisi olduğu düşünülen güven, gizlilik, ve alışveriş keyfi gibi değişkenler arasındaki ilişkiler irdelenmeye çalışılmıştır.

Pazarlama literatürü göz önüne alındığında online (çevrimiçi) alışverişin teknoloji kabul modeliyle açıklanmasına dair yeterli çalışmaya rastlanılamadığından, yapılan bu çalışmanın konuyla ilgili literatüre katkı sağlayacağı düşünülmektedir.

Yapılan bu çalışmanın geri kalan kısmı şu şekilde organize edilmiştir. İkinci bölümde literatür taramasına yer verilmiştir. Üçüncü bölümde kavramsal çerçeve açıklanmıştır. Dördüncü bölümde çalışmanın yönteminden bahsedilmiştir. Beşinci bölümde çalışmadan elde edilen bulgulara yer verilmiştir. "Tartışma ve Sonuç" başlıklı son bölümde ise çalışmadan elde edilen sonuçlar yorumlanmış, çalışmanın kısıtlarından ve gelecekte yapılacak araştırmalar için birtakım önerilerden bahsedilmiştir." 


\section{Literatür Taraması}

Hem online alışveriş hemde TKM ile ilgili literatürde yapılan birçok çalışma bulunmaktadır. Ancak literatürde online alışverişi TKM ile entegre eden çalışmaların sayısının sınırlı olduğu gözlemlenmiştir. Aşağıda online alışverişi TKM ile açıklayan çalışmalara ve bu çalışmaların sonuçlarına yer verilmiştir.

Uygun, Özçifçi ve Uslu Divanoğlu (2011), teknoloji kabul modeli (TKM), planlı davranış kuramı (PDK), yenilik yayılım kuramı (YYK) ve kullanımlar ve tatminler kuramına (KTK) dayalı olarak online tüketici davranışını etkileyen faktörleri teknoloji ve tüketici yönlü bakış açısıyla inceledikleri çalışmalarında hem teknoloji yönlü hem de tüketici yönlü değişkenlerin online tüketici davranışını etkilediği sonucuna ulaşmışlardır.

Çetinsöz (2015), yerli turistlerin turistik mal veya hizmetlere yönelik e-satın alma eğilimlerini belirlemek amacıyla TKM modelinden yararlanmıştır. Araştırma sonucunda algılanan kullanım kolaylığı ve güven yerli turistlerin e-satın alma tutumlarını anlamlı ve pozitif bir şekilde etkilerken algılanan riskin ise anlamlı ve negatif bir etkiye sahip olduğu belirlenmiştir.

Yllmaz (2018), tüketicilerin online alışveriş sitelerini kullanma niyetlerinde hangi faktörlerin etkili olduğunu tespit etmek amaciyla TKM modelini kullanmıştır. Yapılan analizler sonucunda algılanan kullanım kolaylığının hem algılanan fayda hem de online alışveriş niyeti üzerinde pozitif yönlü etkisi olduğu, algılanan ürün riskinin ise algılanan fayda ve online alışveriş niyetini negatif yönde etkilediği tespit edilmiştir.

Vijayasarathy (2004), tüketicilerin online alışveriş yaparken hangi faktörlerden etkilendiğini tespit etmek amacıyla genişletilmiş teknoloji kabul modelinden faydalanmıştır. Yapılan çalışmalar sonucunda tüketicilerin online alışveriş davranışlarını tahmin etmede algılanan kullanışlılık, algılanan kullanım kolaylığı, uyumluluk, gizlilik, normatif inançlar ve öz yeterliliğin tahminlemede etkili olduğu güvenlik değişkeninin ise etkili olmadığı sonucuna ulaşılmıştır. 
Şen (2017), teknoloji kabul modeli, planlı davranış teorisi ve yenilik yayılım kuramına dayalı olarak internet kullanıcılarının online alışveriş yapma davranışlarını etkileyen faktörleri analiz etmek amacıyla yapmış olduğu çalışmasında; algılanan davranışsal kontrolün, subjektif normun, algılanan faydanın, algılanan kullanım kolaylığının, tüketici yenilikçiliğinin, ilgi alanına özel yenilikçiliğin, tüketici alışkanlıklarının ve güvenin online alışveriş davranışı üzerinde etkisi olduğunu tespit etmiştir.

\section{Kavramsal Çerçeve}

Tüketicilerin Online Alş̧veriş Davranışını Etkileyen Faktörler: Tüketicilerin online alışveriş davranışı üzerinde etkisi bulunan olumlu yada olumsuz birçok faktör vardır. Literatürdeki yapılan çalışmalar göz önünde bulundurulduğunda tüketicinin bir ürünü online olarak satın almasına neden ya da engel olan en önemli faktörlerin; gizlilik, güvenlik ve güven, zaman kazanma, kullanım kolaylığı ve alışveriş keyfi olduğu tespit edilmiştir (El-Hassan, 2016, s.13).

Gizlilik; gizli kalması ya da gizli tutulması gereken bir şey olarak ifade edilebilir (Aslanyürek, 2016, s.84). Bireyin, online alışveriş yapmasını engelleyen en önemli faktör bilgilerin saklanması hususunda sitenin güvensizlik veren tavrı ve bilgilerin kötüye kullanılması gibi olasılığın kişilerde ortaya çıkardığı güvensizlik problemidir (Eastlick, Lotz ve Warrington, 2006, s.877). Çoğu zaman insanlar online alışveriş yaparken bir takım kişisel bilgilerini siteyle paylaşmak zorundadır. Bu durumda ticari internet sitelerine güven duyulmasını sağlayan gizlilik kuralları, tüketicinin niyetini olumlu yönde değiştirmek adına önemlidir (Elhassan, 2016, s.15). Güvenlik, bilginin kullanılabilirliğini, bütünlügünü ve gizliliğini korumak olarak ifade edilebilir (Yağcl, ElHassan ve Doğrul, 2017, s.114). Güven ise; satıcının tüketiciye karş1 vermiş olduğu sözü tutması, tüketicinin sipariş verdiği ürün ve hizmeti belirlenen zamanda teslim etmesi olarak tanımlanabilir (Aksoy ve Sever, 2012, s.155).

Online alışveriş, zamanının büyük bir çoğunluğunu mağazada geçirmek istemeyen tüketiciler için iyi bir alternatiftir. Bir çok tüketici tarafından tercih edilen online alışverişin tercih edilme sebebi sağlamış 
olduğu zaman tasarrufudur (Uslu, 2018, s.61). Online alışveriş tüketicilere zaman kaybettirmeden, günün istenilen saatinde kolay bir şekilde ürünleri satın almasına olanak sağlamaktadır (Yıldırım, 2017, s.28). Yapılan çalışmaların ortaya çıkardığı sonuçlarda online alışveriş yapan insanların, geleneksel sistemle alışveriş yapan insanlardan çok daha az zaman harcadıklarını göstermektedir (Enginkaya, 2006, s.12). Kullanım kolaylığı faktörü, tüketicilerin online alışveriş davranışı üzerinde etkisi bulunan bir diğer faktördür. Online alışveriş, geleneksel alışverişe oranla daha hızlı ve daha az zaman harcanarak yapıldığı için tüketiciye büyük kolaylık sağlamaktadır (Ersoy, 2016, s.124). Bu yüzden insanların birçoğu online alışverişi tercih etmektedirler. Alışveriş keyfi sadece geleneksel alışverişi ilgilendiren bir husus değildir. Tüketiciler online alışveriş yaparken de keyif almak istemektedir. Keyif alma unsuru kişinin alışverişi üzerinde olumlu bir etkiye sahiptir. Ticaret siteleri online alışverişlerde keyif unsurunu ortaya çıkarmak için farklı pazarlama yöntemleri uygulamakta, müşterilerine promosyonlar sunmaktadır. Bu sayede farklı ve eğlenceli alışveriş siteleri ortaya çıkmaktadır. Bu da online alışverişi keyifli hale getirmektedir (ElHassan, 2016, s.19).

\section{Teknolojinin Benimsenmesinde Kullanılan Teorik Model (TKM):}

Günümüzün vazgeçilmez bir unsuru olan bilgi teknolojileri hayatımızın her alanında yer almaktadır. Hayatın her alanında yer alan bilgi teknolojilerinin yaygınlaşması ve günlük yaşamda etkili bir rol oynaması nedeniyle teknolojinin kullanımı ve kabulü araştırılması gereken bir alan haline dönüşmüştür (Zeren, 2014, s.171). Bilgi teknolojileri bazı sektörlerde hemen kabul edilirken bazı sektörlerde dirençle karşılaşmış ve yayılması zaman almıştır (Kaş, 2015, s.37). Çelik ve Bindak (2005)'ın da belirttiği gibi insanlar bilmedikleri ya da kullanamayacağını düşündükleri yeniliklere karşı ön yargılı davranmakta ve kabul etmeme konusunda yeniliklere karşı tepki ve direnç göstermektedirler. Bireyler tarafından geliştirilen bu tepki ve direncin nelerden kaynaklandığını bilmek organizasyonlar için önem arz etmektedir (Turan, 2011, s.25). Bilgi teknolojileri kayda değer maliyet tasarrufu ve hizmet artışı sağlamasina rağmen bireylerin bu teknolojileri neden tercih etmediklerini bilmek önemlidir (Turan ve Özgen, 2009, s.135). İnsanın 
bilgi teknolojilerinin gelişimi ve kullanımı karşısındaki tutum ve davranışları, teknolojiyi kabul edip etmediğinin bir göstergesi olarak kabul edilir. Bu bağlamda aşağıdaki sorular önem arzetmektedir (Özer, Özcan ve Aktaş, 2010, s.3279);

- Kullanici sunulan teknolojiyi niçin kabul etmekte veya reddetmektedir?

- Sergiledikleri davranışların nedenleri nelerdir?

- Kullanıc bilgi teknolojilerini kabul etmiş ve kullaniyorsa bunun arkasında yatan nedenler nelerdir? Kullanıcı gelecekte de bilgi teknolojisini kullanmaya devam edecek mi?

Tüm bu soruları cevaplamak için teknoloji kabulünün nasıl gerçekleştiğini ortaya koyan "niyet modelleri" (Intention Model) önerilmiştir (Kaş, 2015, s.37). Niyet modelleri, bireylerin sergilemiş olduğu davranışın kendilerine getireceği yararları yada faydaları hesaplayarak birçok alternatif arasından karar verdiklerini kabul eden tutumların davranışlar üzerindeki etkisini tahmin etmeye yarayan modellerdir (Kahya, 2015, s.48).

Bireyin davranış şekillerini ve bunun altında yatan nedenleri araştıran modeller genellikle psikoloji bilimi tarafından geliştirilmiş ve farklı disiplinler tarafından kullanılmıştır. Bahsedilen bu modelden biri de TKM'dir (Türker, 2013, s.286). TKM, kullanıcıların yeni teknolojiler karşısında göstermiş oldukları direnci, teknoloji kabulünün altında yatan sebepleri ve son olarak kullanıcıların yeni teknolojilere verecekleri cevapları tahmin etmeyi ve sistemde meydana gelen değişiklikle beraber gerçek kullanımdaki gelişmeyi ortaya çıkarmayı amaçlamaktadır (Özer, Özcan ve Aktaş, 2010, s.2). Temeli gerekçeli eylem teorisine (Ajzen ve Fishbein) dayanan TKM, 1986 yılında Davis tarafından geliştirilmiştir. (Çelik ve İpçioğlu, 2006, s.113). Modelin amacı birçok teknolojik yeniliklere genellenebilecek ve bunların kullanımına uygulanabilecek uyum faktörlerini açıklamaktır (Zeren, 2014, s.171).

TKM, bilgi teknoloji kullanımını, özellikle de bireylerin bilgisayar kullanım davranışının açıklanması ve tahmin edilebilmesi için geliştirilmiş bir modeldir (Çetinsöz, 2015, s.2441). TKM, karışık olmayan, basit bir modelle tüm bilgisayar sistemleri için kullanıcı davranışlarını açıklamaktadır. Model sade ve yalın olmasından dolayı teknoloji konusunu kapsayan birçok çalışmada kullanılmıştır (Çakır, 2009, s.12). 
TKM; teknoloji kabulünü algılanan fayda, algılanan kullanım kolaylığı, tutum ve niyet olmak üzere dört temel unsura dayandırarak ölçmektedir (Atik, 2015, s.44-45). Algilanan fayda, bireyin belirli bir bilgi sistemini kullanması sonucunda yapmış olduğu işteki performansının artacağına dair olan inancı olarak tanımlanabilir (Davis, 1989, s.320). Diğer bir ifadeyle kişilerin belirli bir teknolojiyi kullanarak yapmış oldukları işteki performansının artacağına yönelik olumlu algılarıdır (Kalyoncuoğlu, 2018, s.196). Algilanan kullanım kolaylığı, bireyin herhangi bir sistemi kullanırken emek harcamayacağı yönündeki kanısıdır (Bağlıbel, Samancioğulu ve Summak 2010, s.334). Kişinin belirli bir sistemi çaba sarf etmeden kullanması olarak da ifade edilebilir (Pazvant, 2017, s.30). Tutum "Tutulan yol, tavırdır (TDK, 2018). Davranışı sergileyecek olan kişinin o davranışa yönelik olumlu yada olumsuz değerlendirmeleridir (Pazvant, 2017, s.7). Tutum teknolojiyi kullanmaya yönelik; isteme veya istememe olumlu veya olumsuz, lehte veya aleyhte sahip olunan duygular olarak da tanımlanabilir (Akça ve Özer, 2012, s.82). Davranışsal niyet, bir bireyin davranışı sergilemeye hazır bulunması yada bireyin davranışı gerçekleştirmeye ne kadar istekli olduğunun bir göstergesidir (Akıncı ve Kıymalıŏlu, 2014, s.395)

\section{Yöntem}

Çalışmada katılımcılara anket uygulanarak veriler elde edilmiştir. Oluşturulan anket formu amaçlı örneklem yöntemiyle süpermarketlerden en az bir kez online alışveriş yapan süpermarket tüketicilerine 2019 yılında uygulanmıştır. Toplamda 604 kişiye anket uygulanmıştır.

Anket formunda yer alan ifadelerin oluşturulmasinda Turan (2011), Gümüşsoy (2009), Erdem (2011), Peker (2010), Başgöze (2010), Akbaba (2018), Mohamad El Hassan (2016) ve Davis'in (1986) çalışmalarından faydalanılmıştır. Anket toplamda dört bölümden oluşmaktadır. Anketin birinci bölümünde tüketicilerin demografik özelliklerini ölçen ifadelere; ikinci bölümünde tüketicilerin internet ile ilgili davranışlarını ölçen ifadelere; üçünçü bölümde tüketicilerin online alışveriş davranışını ölçen ifadelere yer verilmiştir. Anketin son bölümündeki ifadeler ise teknoloji 
kabul modelinin ana değişkenlerini ölçmeye yöneliktir. Bu ifadelerin değerlendirilmesinde 5'li likert ölçeği kullanılmıştır.

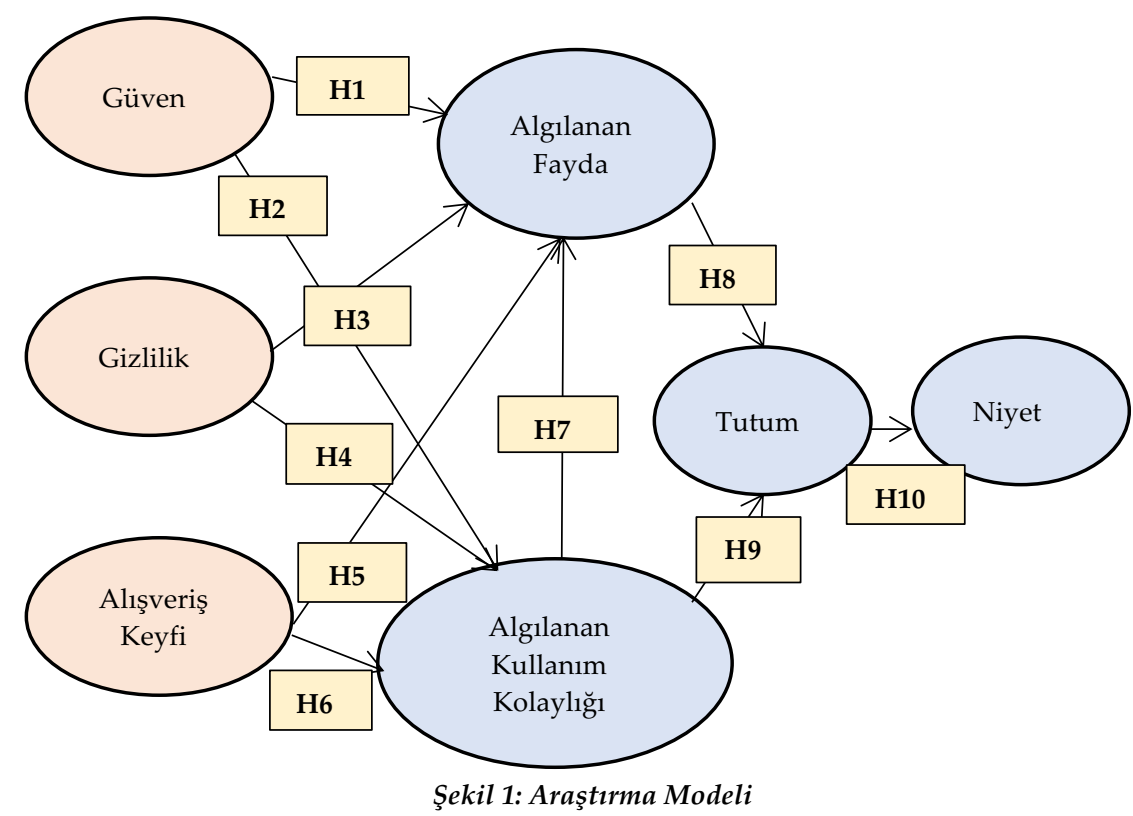

\section{Araştırmanın Hipotezleri}

H1: Güven, algılanan faydayı istatistikî olarak anlamlı bir biçimde etkiler.

H2: Güven, algılanan kullanım kolaylığını istatistikî olarak anlamlı bir biçimde etkiler.

H3: Gizlilik, algılanan faydayı istatistikî olarak anlamlı bir biçimde etkiler.

H4: Gizlilik, algılanan kullanım kolaylığını istatistikî olarak anlamlı bir biçimde etkiler.

H5: Alışveriş keyfi, algılanan faydayı istatistikî olarak anlamlı bir biçimde etkiler.

H6: Alışveriş keyfi algılanan kullanım kolaylığını istatistikî olarak anlamlı bir biçimde etkiler. 
H7: Algılanan kullanım kolaylı̆̆ı, algılanan faydayı istatistikî olarak anlamlı bir biçimde etkiler.

H8: Algılanan fayda, tutumu istatistikî olarak anlamlı bir biçimde etkiler.

H9: Algılanan kullanım kolaylığı, tutumu istatistikî olarak anlamlı bir biçimde etkiler

H10: Tutum, niyeti istatistikî olarak anlamlı bir biçimde etkiler.

\section{Örneklem}

Araştırmanın ana kütlesini Türkiye'de yaşayan süpermarketlerden en az bir kez alışveriş yaptığı tespit edilen süpermarket tüketicileri oluşturmaktadır. Araştırmanın örnekleminin \% 70'ini Konya ilinde yaşayan, geri kalan \%30'luk kısmını ise Karaman, Adana, Ankara, Gaziantep, Mersin, Antalya, İstanbul illerinde yaşayan süpermarket tüketicileri oluşturmaktadır.

\section{Verilerin Analizi}

Araştırmanın amacına ulaşabilmek için toplanan veriler SPSS 21 paket programinda analiz edilmiştir. Örneklemin demografik özelliklerine ilişkin tanımlayıcı istatistiki analiz yapılmıştır. Ölçeğe ilişkin yapı geçerliliğini tespit edebilmek amacıyla açıklayıcı faktör analizi, ölçek ifadelerinin içsel tutarlılığını test etmek amacıyla Cronbach's Alfa katsayıları hesaplanmıştır. Analiz sırasında kullanılacak testlere ilişkin karar, verilerin normal dağılım gösterme durumuna göre verilmektedir. $\mathrm{Bu}$ nedenle verilere normallik testi yapılmış, basıklık ve çarpıklık katsayıları incelenmiştir. Değişkenler arasında bir ilişki olup olmadığını, eğer ilişki var ise bunun yönünü tespit etmek amacıyla korelasyon analizi yapılmıştır. Bir değişkenin diğer bir değişkeni açılama gücünü tespit edebilmek amacıyla basit doğrusal regresyon analizi, ilişkinin yönünü ve gücünü belirlemek için de korelasyon analizi yapılmıştır. Bahsedilen analizlere ilişkin sonuçlar aşağıda başlıklar halinde ele alınmıştır. 
Açıklayıcı Faktör Analizi: Bu çalışmada faktör analizi yapılmadan önce ifadelerin ve faktörlerin ilişkilerinin faktör analizine uygun olup olmadığını belirlemek amacıyla Kaiser-Meyer-Olkin (KMO) Örneklem Yeterlilik Testi ve Bartlett Küresellik Testi yapılmıştır. İfadeler arasındaki ilişkinin faktör analizine uygun olabilmesi için Bartlett küresellik testi anlamlılığını ,000 çıkması gerekmektedir. Diğer taraftan Kaiser-MeyerOlkin (KMO) örneklem yeterlilik testi de değişkenlerin faktör analize uygun olup olmadığını test etmektedir. Kaiser-Meyer-Olkin (KMO) örneklem yeterlilik testi sonucunun 1'e yakın çıması değişkenler arasında mükemmel bir ilişki olduğunu göstermektedir (Pazvant, 2017, s.55). KMO değeri 0,941 olmasından dolayı değişkenlerin faktör analizine uygunluğu mükemmel olduğu ve Bartlett test sonucuna göre anlamlılık $\mathrm{P}=0,000$ olduğu görülmektedir. $\mathrm{Bu}$ durumda $\mathrm{KMO}$ ve Bartlett test sonucuna göre değişkenlere faktör analizi yapılması uygundur. Yapılan analiz sonucunda yedi faktörlü bir yapının ortaya çıtığı görülmektedir. $\mathrm{Bu}$ faktörler algılanan fayda, algilanan kullanım kolaylığı, tutum, niyet, gizlilik, güven ve alışveriş keyfidir. Bu 7 faktör tüm yapıdaki değişimin (varyansın) yaklaşık yüzde 74 'ünü açıklamaktadır.

Ölçeklerin Güvenilirlik ve Geçerliliği: Yapılan çalışmada ölçeklerin ayrı ayrı güvenirliliğinin ve toplam anket güvenilirliğinin ölçülmesinde Cronbach's Alpha $(\alpha)$ katsayısı kullanılmıştır. Literatür göz önünde bulundurulduğunda çoğu zaman $(\alpha)$ değerinin 0.70 ve üzeri olması durumunda ölçeğin güvenilir olduğu kabul edilir (Durmuş, Yurtkoru ve Çinko 2013, s.89). Yapılan bu çalışmada $(\alpha)$ değeri 0,748 ile 0,951 arasında değişmektedir.Katılımcılar tarafından tüm anket sorularına verilen cevapların güvenirliliği incelendiğinde ise alpha değerinin 0,953 olduğu görülmektedir. Bu değerin yüksek olması çalışmada kullanılan ölçeklerin yüksek derecede güvenilir olduğunu göstermektedir (Tablo 1)

Tablo 1. Ölçek Güvenilirlik Skorları

\begin{tabular}{ll}
\hline Ölçekler & Cronbach Alpha \\
\hline Algılanan Fayda & 0,869 \\
Algılanan Kullanım Kolaylı̆̆ı & 0,923 \\
Tutum & 0,829 \\
Niyet & 0,901
\end{tabular}




\section{Verilerin Normallik Analizi}

Analiz sırasında kullanılacak olan testler, verilerin normal dağılım gösterme durumuna göre parametrik ya da parametrik olmayan testler şeklinde yapılmaktadır. Anket formunda yer alan 40 ifadenin normallik testini yapmak için Skewness ve Kurtosis analizleri yapılarak verilerin çarpıklık ve basıklık değerleri saptanmıştır. Tablo 2'de görüldüğü üzere basıklık ve çarpıklık değerlerinin de tavsiye edilen +2 ile -2 değerleri arasında yer aldığı görülmektedir (Başgöze, 2010, s.113). Dolayısıyla çarpıklık ve basıklık katsayısı verinin normal dağılımını desteklediği için parametrik testler yapılmıştır.

Tablo 2. Anket Formunda Yer Alan Ifadelerin Normallik Testi

\begin{tabular}{|c|c|c|c|}
\hline IFADELER & & Çarpıklık & Basıklık \\
\hline \multirow{5}{*}{$\begin{array}{l}\text { ALGILANAN } \\
\text { FAYDA }\end{array}$} & Alışverişte geçirdiğim zamanı azaltır. &,- 540 &,- 946 \\
\hline & $\begin{array}{l}\text { Günlük hayattaki işlerimde daha verimli olmamı } \\
\text { sağlar. }\end{array}$ &,- 384 &,- 898 \\
\hline & $\begin{array}{l}\text { Günlük hayattaki diğer işlerime daha fazla zaman } \\
\text { ayırmamı sağlar. }\end{array}$ &,- 705 &,- 493 \\
\hline & İhtiyacımdan fazla alışveriş yapmama neden olur. &,- 030 & $-1,024$ \\
\hline & $\begin{array}{l}\text { Harcamalarımı daha iyi hesap etmemi ve daha iyi } \\
\text { kontrol etmemi sağlar. }\end{array}$ &,- 406 &,- 887 \\
\hline \multirow{6}{*}{$\begin{array}{l}\text { ALGILANAN } \\
\text { KULLANIM } \\
\text { KOLAYLIĞI }\end{array}$} & Daha kolaydır. & $-1,008$ & ,113 \\
\hline & Zahmet gerektirmez. &,- 872 &,- 221 \\
\hline & $\begin{array}{l}\text { Sadece incelemek istediğiniz ürün grubuna ulaşabilme } \\
\text { imkanı sunar. }\end{array}$ &,- 872 &,- 206 \\
\hline & Müşteri hizmetleri desteği imkanı sunar. &,- 665 &,- 505 \\
\hline & Koşulsuz iade imkanı vardır &,- 278 &,- 905 \\
\hline & İade prosedürleri kolaydır / kısadır. &,- 238 &,- 984 \\
\hline \multirow{8}{*}{ TUTUM } & İyi bir fikirdir. &,- 820 &,- 126 \\
\hline & Hoşuma gidiyor. &,- 781 &,- 285 \\
\hline & Sikıcıdır. & 687 &,- 267 \\
\hline & Bezdiricidir. & 704 &,- 197 \\
\hline & Kendimi değerli hissettirir. & 057 &,- 924 \\
\hline & Dilediğim zaman alışveriş yapmak beni mutlu ediyor. &,- 625 &,- 645 \\
\hline & Online-Alışveriş yapmak konusunda kararlıyım. &,- 384 &,- 748 \\
\hline & $\begin{array}{l}\text { İnsanlarla olan sosyal iletişimimi kaybetmeme neden } \\
\text { olur. }\end{array}$ & ,343 &,- 922 \\
\hline
\end{tabular}




\begin{tabular}{|c|c|c|c|}
\hline \multirow{4}{*}{ NIYYT } & $\begin{array}{l}\text { Gelecekte de süpermarketlerden online olarak ürün } \\
\text { satın alma niyetindeyim. }\end{array}$ &,- 236 &,- 909 \\
\hline & $\begin{array}{l}\text { Her zaman süpermarketlerden online olarak alışveriş } \\
\text { yapmak için çaba göstereceğim. }\end{array}$ & ,124 &,- 887 \\
\hline & $\begin{array}{l}\text { Süpermarket mağazalarının online alışveriş için } \\
\text { uygulamış olduğu yenilikleri yakından takip etmeye } \\
\text { çalışacağım. }\end{array}$ &,- 083 & $-1,004$ \\
\hline & $\begin{array}{l}\text { Düzenli olarak aynı online alışveriş sitesinden alışveriş } \\
\text { yapacağım. }\end{array}$ & ,063 &,- 972 \\
\hline \multirow{5}{*}{ GİZLİLIKK } & $\begin{array}{l}\text { Üyelik için istenilen kişisel bilgilerimin rızam olmadan } \\
\text { kullanılabileceğini düşünürüm. }\end{array}$ &,- 008 & $-1,059$ \\
\hline & $\begin{array}{l}\text { Kredi kartı bilgilerimin kötüye kullanılma ihtimali beni } \\
\text { endişelendirir. }\end{array}$ &,- 317 & $-1,030$ \\
\hline & $\begin{array}{l}\text { Kredi kartı bilgilerimin kullanılarak dolandırılmaktan } \\
\text { endişe duyarım. }\end{array}$ &,- 374 & $-1,010$ \\
\hline & Özel yaşamımın daha iyi korunduğunu düşünürüm. &,- 031 &,- 701 \\
\hline & $\begin{array}{l}\text { Aldığım ürünlerin başkaları tarafından bilinmemesi } \\
\text { beni daha iyi hissettirir. }\end{array}$ &,- 189 & $-1,189$ \\
\hline \multirow{9}{*}{ GÜVEN } & $\begin{array}{l}\text { Verilerim profesyonelce korunduğu için kendimi rahat } \\
\text { hissediyorum. }\end{array}$ &,- 096 &,- 611 \\
\hline & $\begin{array}{l}\text { Güvenlik ve gizlilik konusunda açıkların olduğunu } \\
\text { düşünmüyorum. }\end{array}$ &,- 092 &,- 610 \\
\hline & Online alışverişe tam olarak güveniyorum &,- 059 &,- 463 \\
\hline & Online alışverişe güvenilebilir, belirsizlikler yoktur. & 113 &,- 435 \\
\hline & $\begin{array}{l}\text { Benden alınan kişisel bilgilerin güvenli bir şekilde } \\
\text { saklanacağını düşünürüm. }\end{array}$ &,- 143 &,- 520 \\
\hline & Satın aldığım ürünlerin gizli tutulacağından eminim. &,- 212 &,- 434 \\
\hline & $\begin{array}{l}\text { Online alışveriş sitelerini kullanırken herhangi bir } \\
\text { güven problemi yaşamıyorum. }\end{array}$ &,- 155 &,- 653 \\
\hline & Online alışverişte yaptığım işlemlerin güvenliğinden & & \\
\hline & kuşku duymuyorum. &,- 063 &,- 584 \\
\hline \multirow{4}{*}{$\begin{array}{l}\text { ALIŞVERIŞ } \\
\text { KEYFI }\end{array}$} & $\begin{array}{l}\text { Süpermarketlerden online alışveriş yapmaktan keyif } \\
\text { alırım. }\end{array}$ &,- 290 &,- 902 \\
\hline & $\begin{array}{l}\text { Online alışveriş hizmeti sunan şirketlerin web sitelerini } \\
\text { kullanmak zevklidir. }\end{array}$ &,- 458 &,- 637 \\
\hline & $\begin{array}{l}\text { Online alışveriş hizmeti sunan şirketlerin web sitelerini } \\
\text { kullanmak keyiflidir }\end{array}$ &,- 461 &,- 629 \\
\hline & $\begin{array}{l}\text { Online alışveriş hizmeti sunan şirketlerin web sitelerini } \\
\text { kullanmak çok eğlencelidir. }\end{array}$ &,- 375 &,- 711 \\
\hline
\end{tabular}

\section{Bulgular}

Aşağıda katılımcılara ait demografik bilgiler yer almaktadır. Tablo 3 incelendiğinde çalışma grubunun \% 65,7'si kadın iken \%34. 3'ü erkektir. Araştırmaya katılan çalışma grubunun \%16,9'u 18-22, \%49'u 23-27, 
$\% 18,4^{\prime} \ddot{u}$ 28-32, \%8,1'i 33-37, \%4,5'i 38-42, \%3,1'i 43 ve üzeri yaşında olduğu görülmektedir.

Tablo 3. Katılımcılarnn Demografik Özellikleri

\begin{tabular}{|c|c|c|c|}
\hline & & $\mathbf{N}$ & $\%$ \\
\hline \multirow{2}{*}{ Cinsiyet } & Kadın & 397 & 65,7 \\
\hline & Erkek & 207 & 34,3 \\
\hline \multirow{6}{*}{ Yaş } & $18-22$ & 102 & 16,9 \\
\hline & $23-27$ & 296 & 49,0 \\
\hline & $28-32$ & 111 & 18,4 \\
\hline & $33-37$ & 49 & 8,1 \\
\hline & $38-42$ & 27 & 4,5 \\
\hline & 43 ve üzeri & 19 & 3,1 \\
\hline \multirow{7}{*}{ Eğitim } & İlköğretim & 7 & 1,2 \\
\hline & Ortaöğretim & 28 & 4,6 \\
\hline & Lise & 62 & 10,3 \\
\hline & Ön lisans & 59 & 9,8 \\
\hline & Lisans & 322 & 53,3 \\
\hline & Yüksek lisans & 108 & 17,9 \\
\hline & Doktora & 18 & 3,0 \\
\hline \multirow{6}{*}{$\begin{array}{l}\text { Aylık } \\
\text { Gelir }\end{array}$} & $0-1500$ & 242 & 40,1 \\
\hline & $1501-3000$ & 153 & 25,3 \\
\hline & $3001-4500$ & 103 & 17,1 \\
\hline & $4501-6000$ & 65 & 10,8 \\
\hline & $6001-7500$ & 22 & 3,6 \\
\hline & 7500 ve üzeri & 19 & 3,1 \\
\hline
\end{tabular}

Grubun eğitim durumuna bakıldığında \%1,2'sinin ilköğretim, $\% 4,6$ 'sının orta öğretim, \%10,3'ünün lise, \%9,8'inin önlisans, \%53,3'ünün lisans, \%17,9 yüksek lisans, \%3'ü doktora mezunudur. Grubun aylık gelirine bakıldığında \%40,1'inin 0-1500, \%25,3'ünün 1501- 3000, $\% 17,1^{\prime}$ inin $3001-4500, \% 10,8$ 'inin 4501-6000, \%3,6'sinin 6001-7500, \%3,1'inin 7500 ve üzeri gelire sahip olduğu görülmektedir.

Katılımcıların interneti kullanım amaçları ve internette geçirdikleri süreler Tablo 4'de gösterilmektedir. Tablo 4'e göre katılımcıların \%40,1'i interneti; eğlence amaçlı, \%23,5'i iletişim amaçlı, \%22,7'si alışveriş amaçlı $\% 9,6$ 'sı bilgi edinme amaçlı geri kalan \%4,1'i ise bankacılık hizmetleri amacıyla kullandıklarını ifade etmişlerdir. Ayrıca tabloya göre katılımcların \%43,7' sinin günde 1 - 3, \%44,7'sinin 4 - 6, \%9,6'sının 7-10, $\% 2$ 'sinin ise günde 11 saat ve üzeri internet kullandıkları görülmektedir. 
Tablo 4. Katılımcılarn internet kullanma amaçları ve internette geçirdikleri süreler

\begin{tabular}{lll}
\hline Kategori & $\mathbf{N}$ & $\mathbf{\%}$ \\
\hline Alışveriş & 137 & 22,7 \\
Eğlence & 242 & 40,1 \\
Iletişim & 142 & 23,5 \\
Bankacıllk Hiz. & 25 & 4,1 \\
Bilgi Edinme & 58 & 9,6 \\
Kategori & $\mathbf{N}$ & $\mathbf{\%}$ \\
1-3 saat & 264 & 43,7 \\
4-6 saat & 270 & 44,7 \\
$7-10$ saat & 58 & 9,6 \\
11 saat ve üzeri & 12 & 2,0 \\
\hline
\end{tabular}

Katılımcıların online alışveriş davranışı ölçen ifadeler Tablo 5'de verilmiştir. Tabloya göre katılımcıların $\% 15,9^{\prime}$ u son 6 aydır, $\% 13,6$ 'sı son bir yıldır \%14,9'u 1 yıldan çok \% 55,6'sı 2 yıldan çok internetten alışveriş yaptı̆̆ görülmektedir.

Tablo 5. Tüketicilerin Online Alışveriş Davranışını Ölçen İfadeler

\begin{tabular}{|c|c|c|}
\hline \multicolumn{3}{|c|}{ Katılımcıların Online Alışveriş Yapma Süreleri } \\
\hline Kategori & $\mathbf{N}$ & $\%$ \\
\hline Son 6 ay & 96 & 15,9 \\
\hline Son 1 yil & 82 & 13,6 \\
\hline 1 yıldan çok & 90 & 14,9 \\
\hline 2 yıldan çok & 336 & 55,6 \\
\hline \multicolumn{3}{|c|}{ Katılımcıların Online Alışveriş Yaparken Geçirdiği Süreler } \\
\hline Kategori & $\mathbf{N}$ & $\%$ \\
\hline 1 saatten az & 559 & 92,5 \\
\hline $1-3$ saat & 8 & 1,3 \\
\hline 3-5 saat & 22 & 3,6 \\
\hline 5 saatten fazla & 15 & 2,5 \\
\hline \multicolumn{3}{|c|}{ Katılımcıların Online Alışveriş Yapma Sıklıkları } \\
\hline Kategori & $\mathbf{N}$ & $\%$ \\
\hline Haftada bir kez & 23 & 3,8 \\
\hline Haftada birkaç kez & 24 & 4,0 \\
\hline İki haftada birkez & 30 & 5,0 \\
\hline Ayda bir kez & 56 & 9,3 \\
\hline Belirli bir periyot yok & 471 & 78,0 \\
\hline \multicolumn{3}{|c|}{ Katılımcıların Bir Ayda Yaptıkları Online Alışveriş Sayıları } \\
\hline Kategori & $\mathrm{N}$ & $\%$ \\
\hline $0-2$ defa & 532 & 88,1 \\
\hline 3-5 defa & 45 & 7,5 \\
\hline 6-8 defa & 8 & 1,3 \\
\hline 9 ve daha fazla & 19 & 3,1 \\
\hline
\end{tabular}




\begin{tabular}{lll}
\hline Katılimcıların Online Alışveriş İçin Harcadikları Tutarlar \\
Kategori & N & \% \\
$0-500$ & 535 & 88,6 \\
$501-1000$ & 47 & 7,8 \\
$1001-1500$ & 14 & 2,3 \\
$1501-2000$ & 4 & 0,7 \\
$2001-2500$ & 1 & 0,2 \\
2501 ve üzeri & 3 & 0,5 \\
\hline
\end{tabular}

Katılımcıların online alışveriş yaparken geçirdikleri sürelere bakıldığında katılımcıların \%92,5'i online alışverişte 1 saatten az zaman harcarken, geri kalan \% 7,5'i ise 1 saatten fazla zaman harcamaktadır. Katılımcıların \% 3,8'i haftada bir kez online alışveriş yaptığını belirtirken, \%4'ü haftada birkaç kez online alışveriş yaptıklarını belirtmiştir. İki haftada birkaç kez alışveriş yapanların oranı \%5 iken, ayda bir kez alışveriş yapanların sayısı \%9,3'dür. Katılımcıların çoğunluğunu oluşturan \% 78'lik kısmı ise süpermarketlerden belirli bir periyot olmadan alışveriş yaptıklarını belirtmişlerdir. Katılımcıların büyük çoğunluğunu oluşturan \%88,1'i 0-2 defa, \%7,5'i 3-5 defa, \% 1,3'ü, 6-8 defa, \%3,1 'i ise 9 ve daha fazla kez alışveriş yaptıklarını belirtmişlerdir. Katılımcıların \%88,6'sı aylık ortalama süpermarketlerden 0-500 TL arası harcama yaparken, \% 7,8'i 501-1000 TL arasinda harcama yaptıklarını belirtmişlerdir. Katılımcıların \% 3,7'si süpermarketlerden online alışveriş yaparken 1000 TL'den fazla harcadıklarını belirtmişlerdir.

Regresyon Analizi ile Hipotezlerin Test Edilmesi: Regresyon analizi; biri bağımlı, diğeri bağımsız değişken arasında nedensellik ilişkisini arayan bir analiz olup, değişkenler arasındaki ilişkiyi tahmin etmeye yarar (Nakip ve Yaraş, 2017, s.384). Bu çalışmada, her bir bağımsız değişkenin bağımlı değişkenle olan ilişkisini incelemek ve bağımlı değişkeni hangi yönde ve ne kadar açıkladığını belirlemek amacıyla basit doğrusal regresyon analizi yapılmış ve çalışmanın hipotezleri araştırılmıştır. 
Tablo 6. Güven İle Algılanan Fayda Arasındaki İlişkiye Yönelik Basit Regresyon Analiz Sonucu

\begin{tabular}{llclllll}
\hline & Değişkenler & $\mathbf{B}$ & $\begin{array}{l}\text { Standart } \\
\text { Hata }\end{array}$ & $\mathbf{B}$ & $\mathbf{T}$ & $\mathbf{p}$ & Sonuç \\
\hline H1 & $\begin{array}{l}\text { Güven (Sabit) } \\
\text { Algılanan } \\
\text { Fayda }\end{array}$ & 1,801 & 0,115 & - & 15,677 &, 000 & KABUL \\
\hline $\mathbf{R}=, 386$ & 0,345 & 0,034 & 0,386 & 10,274 &, 000 & $\mathbf{R}^{2}=, 149$ \\
\hline
\end{tabular}

Güvenin, algılanan fayda üzerindeki etkisi basit doğrusal regresyon analizi ile test edilmiş ve analiz sonucu istatistiksel olarak anlamlı bulunmuştur $(\mathrm{F}=105,563 \mathrm{p}=, 000<0,05)$. İki değişken arasında $\mathrm{t}$ değerine göre pozitif yönlü anlamlı bir ilişki olduğu sonucuna varılmaktadır ( $\mathrm{t}=$ 15,677). Güven değişkeninin \%14'ü algılanan fayda değişkeni ile açıklanmaktadır. Güvende oluşan bir birimlik artış algılanan fayda üzerinde 0,345'lik artışa yol açmaktadır. "H1: Güven, algılanan faydayı istatistikî olarak anlamlı bir biçimde etkiler" hipotezi kabul edilmiştir ( $F=105,563 \mathrm{p}=, 000<0,05)$.

Tablo 7. Güven İle Algılanan Kullanım Kolaylı̆̆ı Arasındaki İlişkiye Yönelik Basit Regresyon Analiz Sonucu

\begin{tabular}{|c|c|c|c|c|c|c|c|}
\hline & Değişkenler & B & $\begin{array}{l}\text { Standart } \\
\text { Hata }\end{array}$ & B & $\mathrm{T}$ & p & Sonuç \\
\hline \multirow[b]{2}{*}{ H2 } & $\begin{array}{l}\text { Güven } \\
\text { (Sabit) }\end{array}$ & 1,592 & 116 & & 13,674 & ,000 & \multirow[b]{2}{*}{ KABUL } \\
\hline & $\begin{array}{l}\text { Algilanan } \\
\text { Kullanım } \\
\text { Kolaylığı }\end{array}$ & ,382 & ,032 & ,438 & 11,966 & ,000 & \\
\hline $\mathbf{R}=$ & $\mathbf{R}^{2}=, 192 \mathbf{A d}$ & just $R^{2}=$ & $F=143$ & & & & \\
\hline
\end{tabular}

Güvenin, algılanan kullanım kolaylığı üzerinde etkisinin olup olmadığını test etmek amaciyla geliştirilen "H2: Güven, algılanan kullanım kolaylı̆̆ını istatistikî olarak anlamlı bir biçimde etkiler" hipotezinin regresyon analizi sonucu Tablo 7 'de gösterilmiştir. Tablo 7 incelendiğinde regresyon analizi istatistiksel olarak anlaml bulunmuştur. ( $F=143,184 ; p=, 000<0,05)$. İki değişken arasında t değerine göre pozitif yönlü anlamlı bir ilişki olduğu sonucuna varılmaktadır ( $\mathrm{t}=$ 13,674). Güven değişkeninin \%19'u algılanan kullanım kolaylığı ile açıklanmaktadır. Güvende oluşan bir birimlik artış algılanan kullanım 
kolaylığ1 üzerinde 0,382'lik artışa yol açmaktadır. “H2: Güven, algılanan kullanım kolaylığını istatistikî olarak anlamlı bir biçimde etkiler" hipotezi kabul edilmiştir. ( $F=143,184 ; p=, 000<0,05)$.

Tablo 8. Gizlilik İle Algılanan Fayda Arasındaki İlişkiye Yönelik Basit Regresyon Analiz Sonucu

\begin{tabular}{llllllll}
\hline & Değişkenler & $\mathbf{B}$ & $\begin{array}{l}\text { Standart } \\
\text { Hata }\end{array}$ & $\mathbf{B}$ & $\mathbf{t}$ & $\mathbf{P}$ & \multicolumn{2}{c}{ Sonuç } \\
\hline \multirow{2}{*}{$\mathbf{H} 3$} & Gizlilik (Sabit) & 2,278 & 0,117 & & 19,418 &, 000 & \multirow{2}{*}{ KABUL } \\
& Alglanan Fayda & 0,244 & 0,034 & 0,279 & 7,128 &, 000 & \\
\hline $\mathbf{R}=, 279 \quad \mathbf{R}^{2}=, 078$ & Adjust $\mathbf{R}^{2}=, 076$ & $\mathbf{F}=50,812$ & & & & \\
\hline
\end{tabular}

Gizliliğin, algılanan fayda üzerindeki etkisi basit doğrusal regresyon analizi ile test edilmiş ve analiz sonucu istatistiksel olarak anlamlı bulunmuştur $(\mathrm{F}=50,812 \mathrm{p}=, 000<0,05)$. İki değişken arasında $\mathrm{t}$ değerine göre pozitif yönlü anlamlı bir ilişki olduğu sonucuna varılmaktadır ( $\mathrm{t}=$ 19,418). Gizlilik değişkeninin \%7'si algılanan fayda değişkeni ile açıklanmaktadır. Gizlilikte oluşan bir birimlik artış algılanan fayda üzerinde 0,244'lük artışa yol açmaktadır. "H3: Gizlilik, algılanan faydayı istatistikî olarak anlamlı bir biçimde etkiler" hipotezi kabul edilmiştir. $(\mathrm{F}=50,812 \mathrm{p}=, 000<0,05)$.

Tablo 9. Gizlilik İle Algılanan Kullanım Kolaylı̆̆ı Arasındaki İlişkiye Yönelik Basit Regresyon Analiz Sonucu

\begin{tabular}{llclllll}
\hline & Değişkenler & $\mathbf{B}$ & $\begin{array}{l}\text { Standart } \\
\text { Hata }\end{array}$ & $\mathbf{B}$ & $\mathbf{t}$ & $\mathbf{p}$ & Sonuç \\
\hline \multirow{2}{*}{$\mathbf{H 4}$} & Gizlilik (Sabit) & 2,228 &, 122 & & 18,284 &, 000 & \\
& $\begin{array}{l}\text { Algılanan Kullanım } \\
\text { Kolaylığ }\end{array}$ &, 243 &, 033 &, 284 & 7,262 &, 000 & KABUL \\
\hline $\mathbf{R =}=284$ & $\mathbf{R}^{2}=, 081$ Adjust $\mathbf{R}^{2}=, 79$ & $\mathbf{F}=52,737$ & & & & \\
\hline
\end{tabular}

Gizliliğin algılanan kullanım kolaylığı üzerinde etkisinin olup olmadığını test etmek amacıyla geliştirilen H4: Gizlilik, algılanan kullanım kolaylığını istatistikî olarak anlamlı bir biçimde etkiler" hipotezinin regresyon analizi sonucu Tablo 9'da gösterilmiştir. Tablo 9 incelendiğinde regresyon analizi istatistiksel olarak anlaml bulunmuştur. ( $\mathrm{F}=52,737 ; \mathrm{p}=, 000<0,05)$. İki değişken arasında $\mathrm{t}$ değerine göre pozitif yönlü anlamlı bir ilişki olduğu sonucuna varılmaktadır ( $t=$ 
18,284). Gizlilik değişkeninin \%8'i algılanan kullanım kolaylığı ile açıklanmaktadır. Gizlilikte oluşan bir birimlik artış algılanan kullanım kolaylığ1 üzerinde 0,243'lük artışa yol açmaktadır. "H4: Gizlilik, algılanan kullanım kolaylığını istatistikî olarak anlamlı bir biçimde etkiler" hipotezi kabul edilmiştir ( $F=52,737 ; \mathrm{p}=, 000<0,05)$.

Tablo 10. Alışveriş Keyfi İle Algılanan Fayda Arasındaki İlişkiye Yönelik Basit Regresyon Analiz Sonucu

\begin{tabular}{llllllll}
\hline & Değişkenler & $\mathbf{B}$ & $\begin{array}{l}\text { Standart } \\
\text { Hata }\end{array}$ & B & T & p & Sonuç \\
\hline H5 & Alışveriş Keyfi ( Sabit) & 1,461 & 0,128 & & 11,402 &, 000 & \multirow{2}{*}{ KABUL } \\
& Algılanan Fayda & 0,551 & 0,037 & 0,515 & 14,729 &, 000 & \\
\hline $\mathbf{R}=, 515$ & $\mathbf{R}^{2}=, 265 \quad$ Adjust $\mathbf{R}^{2}=264$ & $\mathbf{F}=216,947$ & & & & \\
\hline
\end{tabular}

Alışveriş keyfinin, algılanan fayda üzerinde etkisinin olup olmadığını test etmek amacıyla geliştirilen "H5: Alışveriş keyfi, algılanan faydayı istatistikî olarak anlamlı bir biçimde etkiler" hipotezinin regresyon analizi sonucu Tablo 10 'da gösterilmiştir. Tablo 10 incelendiğinde regresyon analizi istatistiksel olarak anlamlı bulunmuştur. ( $\mathrm{F}=216,947$; $\mathrm{p}=, 000<0,05)$. İki değişken arasında $t$ değerine göre pozitif yönlü anlamlı bir ilişki olduğu sonucuna varılmaktadır $(\mathrm{t}=11,402)$. Alışveriş keyfi değişkeninin \%26,5'i algılanan fayda ile açıklanmaktadır. Alışveriş keyfinde oluşan bir birimlik artış algılanan fayda üzerinde 0,551'lik artışa yol açmaktadır. H5: Alışveriş keyfi, algılanan faydayı istatistikî olarak anlamlı bir biçimde etkiler" hipotezi kabul edilmiştir. ( $\mathrm{F}=216,947$; $\mathrm{p}=, 000<0,05)$.

Tablo 11. Alışveriş Keyfi İle Algılanan Kullanım Kolaylı̆̆ı Arasındaki İlişkiye Yönelik Basit Regresyon Analiz Sonucu

\begin{tabular}{llllllll}
\hline & Değişkenler & $\mathbf{B}$ & $\begin{array}{l}\text { Standart } \\
\text { Hata }\end{array}$ & $\mathbf{B}$ & $\mathbf{t}$ & $\mathbf{P}$ & Sonuç \\
\hline \multirow{2}{*}{$\mathbf{H 6}$} & $\begin{array}{l}\text { Alışveriş Keyfi ( Sabit) } \\
\text { Algılanan Kullanım }\end{array}$ & 1,132 & 0,126 & & 8,962 &, 000 & \multirow{2}{*}{$\begin{array}{l}\text { KABUL } \\
\text { Kolaylığ }\end{array}$} \\
\hline $\mathbf{R = , 5 8 3}$ & $\mathbf{R}^{2}=, 340$ Adjust $\mathbf{R}^{2}=, 339$ & $\mathbf{F}=309,705$ & 0,035 & 0,583 & 17,598 &, 000 & \\
\hline
\end{tabular}

Alışveriş keyfi değişkeninin, algılanan kullanım kolaylığı üzerindeki etkisi Tablo 11'de gösterilmiştir. Tablo 11 incelendiğinde “H6: Alışveriş 
keyfi algılanan kullanım kolaylığını istatistikî olarak anlamlı bir biçimde etkiler" hipotezinin regresyon analizi istatistiksel olarak anlamlı bulunmuştur. ( $F=309,705 ; \mathrm{p}=, 000<0,05)$. İki değişken arasında t değerine göre pozitif yönlü anlamlı bir ilişki olduğu sonucuna varılmaktadır ( $t=$ 8,962). Alışveriş keyfi değişkeninin \%34'ü algılanan kullanım kolaylığ ile açılanmaktadır. Alışveriş keyfinde oluşan bir birimlik artış algılanan kullanım kolaylığı üzerinde 0,61'lik artışa yol açmaktadır. "H6: Alışveriş keyfi algılanan kullanım kolaylığını istatistikî olarak anlamlı bir biçimde etkiler" hipotezi kabul edilmiştir. ( $F=309,705 ; \mathrm{p}=, 000<0,05)$.

Tablo 12. Algılanan Kullanım Kolaylı̆̆ı İle Algılanan Fayda Arasındaki İlişkiye Yönelik Basit Regresyon Analiz Sonucu

\begin{tabular}{llllllll}
\hline & Değişkenler & B & $\begin{array}{l}\text { Standart } \\
\text { Hata }\end{array}$ & B & T & p & Sonuç \\
\hline H7 & $\begin{array}{l}\text { Algılanan Kullanım } \\
\text { Kolaylığ (Sabit) } \\
\text { Algılanan Fayda }\end{array}$ &, 825 &, 086 & & 9,575 &, 000 & KABUL \\
&, 816 &, 025 &, 798 & 32,438 &, 000 & \\
\hline $\mathbf{R}=, 798$ & $\mathbf{R}^{2}=, 636$ Adjust $\mathbf{R}^{2}=635$ & $\mathbf{F}=1052,198$ & & & & \\
\hline
\end{tabular}

Algılanan kullanım kolaylığı değişkeninin, algılanan fayda üzerindeki etkisi Tablo 12' de gösterilmiştir. Tablo 12 incelendiğinde "H7: Algılanan kullanım kolaylığı, algılanan faydayı istatistikî olarak anlamlı bir biçimde etkiler" hipotezinin regresyon analizi istatistiksel olarak anlamlı bulunmuştur. ( $F=1052,198 ; \mathrm{p}=, 000<0,05)$. İki değişken arasında $t$ değerine göre pozitif yönlü anlamlı bir ilişki olduğu sonucuna varılmaktadır $(\mathrm{t}=9,575)$. Algılanan kullanım kolaylığı değişkeninin \%63'ü algılanan fayda ile açılanmaktadır. Algılanan kullanım kolaylığında oluşan bir birimlik artış algılanan fayda üzerinde $0,816^{\prime}$ lık artışa yol açmaktadır. "H7: Algılanan kullanım kolaylığı, algılanan faydayı istatistikî olarak anlamlı bir biçimde etkiler" hipotezi kabul edilmiştir ( $\mathrm{F}=1052,198 ; \mathrm{p}=, 000<0,05)$.

Algılanan fayda değişkeninin, tutum üzerindeki etkisi Tablo 13'de gösterilmiştir. Tablo 13 incelendiğinde "H8: Algılanan fayda, tutumu istatistikî olarak anlamlı bir biçimde etkiler" hipotezinin regresyon analizi istatistiksel olarak anlamlı bulunmuştur. ( $F=498,397 ; \mathrm{p}=, 000<0,05)$. 
Tablo 13. Algılanan Fayda İle Tutum Arasındaki İlişkiye Yönelik Basit Regresyon Analiz Sonucu

\begin{tabular}{llllllll}
\hline & Değişkenler & B & $\begin{array}{l}\text { Standart } \\
\text { Hata }\end{array}$ & B & T & p & Sonuç \\
\hline H8 & $\begin{array}{l}\text { Algılanan Fayda } \\
\text { (Sabit) }\end{array}$ & 0,754 & 0,117 & & 6,459 &, 000 & KABUL \\
& $\begin{array}{l}\text { Tutum } \\
\mathbf{R}=, 673\end{array}$ & $\mathbf{R}^{2}=, 453$ Adjust $\mathbf{R}^{2}=, 452$ & $\mathbf{F}=498,397$ & & & & \\
\hline
\end{tabular}

İki değişken arasında $t$ değerine göre pozitif yönlü anlamlı bir ilişki olduğu sonucuna varılmaktadır $(\mathrm{t}=6,459)$. Algılanan fayda değişkeninin $\% 45$ 'i tutum ile açıklanmaktadır. Algılanan faydada oluşan bir birimlik artış tutum üzerinde 0,856'lık artışa yol açmaktadır. "H8: Algılanan fayda, tutumu istatistikî olarak anlamlı bir biçimde etkiler" hipotezi kabul edilmiştir. ( $\mathrm{F}=498,397 ; \mathrm{p}=, 000<0,05)$.

Tablo 14. Algılanan Kullanım Kolaylı̆̆ı İle Tutum Arasındaki İlişkiye Yönelik Basit Regresyon Analiz Sonucu

\begin{tabular}{llllllll}
\hline & Değişkenler & $\mathbf{B}$ & $\begin{array}{l}\text { Standart } \\
\text { Hata }\end{array}$ & $\mathbf{B}$ & $\mathbf{t}$ & $\mathbf{p}$ & Sonuç \\
\hline $\begin{array}{l}\text { Algılanan kullanım } \\
\text { kolaylığ }\end{array}$ (Sabit) & 0,703 & 0,11 & & 6,364 & 0,00 & KABUL \\
$\quad$ & 0,949 & 0,036 & 0,73 & 26,187 & 0,00 & \\
\hline $\mathbf{R}=, \mathbf{7 3 0} \quad \mathbf{R}^{2}=, \mathbf{5 3 3}$ & Adjust $\mathbf{R}^{2}=, \mathbf{5 3 2}$ & $\mathbf{F}=\mathbf{6 8 5 , 7 6 1}$ & & & & \\
\hline
\end{tabular}

Algılanan kullanım kolaylığ 1 değişkeninin, tutum üzerindeki etkisi Tablo 14'de gösterilmiştir. Tablo 14 incelendiğinde "H9: Algılanan kullanım kolaylığı, tutumu istatistikî olarak anlamlı bir biçimde etkiler" hipotezinin regresyon analizi istatistiksel olarak anlamlı bulunmuştur. $(\mathrm{F}=685,761 ; \mathrm{p}=, 000<0,05)$. İki değişken arasında $\mathrm{t}$ değerine göre pozitif yönlü anlamlı bir ilişki olduğu sonucuna varılmaktadır $(t=6,364)$. Algılanan kullanım kolaylığı değişkeninin \%53'ü tutum ile açıklanmaktadır. Algılanan kullanım kolaylığındaki oluşan bir birimlik artış tutum üzerinde 0,949'luk artışa yol açmaktadır. "H9: Algılanan kullanım kolaylı̆̆ı, tutumu istatistikî olarak anlamlı bir biçimde etkiler" hipotezi kabul edilmiştir. ( $\mathrm{F}=685,761 ; \mathrm{p}=, 000<0,05)$.

Tutum değişkeninin, niyet üzerindeki etkisi Tablo $15^{\prime}$ de gösterilmiştir. Tablo 15 incelendiğinde "H10: Tutum, niyeti istatistikî 
olarak anlamlı bir biçimde etkiler" hipotezinin regresyon analizi istatistiksel olarak anlamlı bulunmuştur. ( $F=567,884 ; p=, 000<0,05)$.

Tablo 15. Tutum Ille Niyet Arasındaki İlişkiye Yönelik Basit Regresyon Analiz Sonucu

\begin{tabular}{llclllll}
\hline & Değişkenler & $\mathbf{B}$ & $\begin{array}{l}\text { Standart } \\
\text { Hata }\end{array}$ & $\mathbf{B}$ & $\mathbf{t}$ & $\mathrm{p}$ & Sonuç \\
\hline \multirow{2}{*}{$\mathrm{H} 10$} & Tutum (Sabit) & 1,441 &, 067 & & 21,479 &, 000 & \multirow{2}{*}{ KABUL } \\
& Niyet &, 515 &, 022 &, 697 & 23,830 &, 000 & \\
\hline $\mathbf{R}=, 730$ & $\mathbf{R}^{2}=, 533$ & Adjust $\mathbf{R}^{2}=, 532$ & $\mathbf{F}=685,761$ & & & & \\
\hline
\end{tabular}

İki değişken arasında $t$ değerine göre pozitif yönlü anlamlı bir ilişki olduğu sonucuna varılmaktadır $(\mathrm{t}=21,479)$. Tutum değişkeninin $\% 48,5^{\prime} \mathrm{i}$ niyet ile açıklanmaktadır. Tutumda oluşan bir birimlik artış niyet üzerinde 0,515'lik artışa yol açmaktadır. "H10: Tutum, niyeti istatistikî olarak anlamlı bir biçimde etkiler" hipotezi kabul edilmiştir ( $\mathrm{F}=567,884$; $\mathrm{p}=, 000<0,05)$.

Korelasyon Analizi: Değişkenler arasındaki ilişki farklı şekillerde olabilir. Değişkenlerden biri artarken diğeri de artıyor ya da biri azalırken diğeri de azalıyorsa bu iki değişken arasında pozitif yönlü ilişki vardır. Ancak değişkenlerden biri artarken diğeri azalıyorsa bu değişken arasında negatif ilişki vardır. Korelasyon katsayısı bu iki değişken arasındaki ilişkinin kuvvetini göstermektedir (Pazvant, 2017: 58). Korelasyon katsayısı " $r$ " ile gösterilir ve -1 ile +1 arasında bir değer alır. $r$ değerinin -1 olması değişkenler arasında tam negatif doğrusal bir ilişki olduğu anlamına, +1 olması tam pozitif doğrusal bir ilişki olduğunu anlamına, 0 olması ise iki değişken arasında ilişkinin olmadığ anlamina gelmektedir (Tepe, 2018, s.97).

Değişkenlere ilişkin korelasyon tablosu incelendiğinde korelasyon katsayılarına göre ikili seviyede $\left(^{* *}\right)$ pozitif anlamlılık olduğu görülmektedir. Tablo $16^{\prime}$ da yer alan veriler incelendiğinde algilanan fayda ile algılanan kullanım kolaylığ $(\mathrm{r}=, 798)$, tutum $(\mathrm{r}=, 673)$, alışveriş keyfi $(\mathrm{r}=, 515)$ arasında yüksek düzeyde anlamlı ve pozitif yönlü bir ilişki var iken algilanan fayda ile gizlilik $(\mathrm{r}=, 279)$, güven $(\mathrm{r}=, 386)$ arasında düşük düzeyde anlamlı pozitif yönlü bir ilişki olduğu görülmektedir. 
Tablo 16. Değişkenlere İlişkin Korelasyon Tablosu

\begin{tabular}{|c|c|c|c|c|c|c|c|c|c|}
\hline & Ort & SS & AF & AKK & $T$ & $\mathbf{N}$ & GIZ & G & AK \\
\hline AF & 3,2 & 1,0 & 1 & & & & & & \\
\hline AKK & 3,4 & 1,0 & ,798* & 1 & & & & & \\
\hline$T$ & 2,9 & ,80 & ,673* & ,730* & 1 & & & & \\
\hline $\mathbf{N}$ & 2,9 & 1,0 & ,537* & ,650* & ,697* & 1 & & & \\
\hline GİZ & 3,0 & 89 & ,279* & ,284* & ,288* & $176^{* *}$ & 1 & & \\
\hline G & 2,9 & 91 & ,386* & $438^{*}$ & ,382* &, $429^{* *}$ & 0,01 & 1 & \\
\hline AK & 3,2 & 1,0 &, $515^{*}$ &, $583^{*}$ &, $512^{*}$ &, $573^{* *}$ &, $220^{*}$ &, $494^{*}$ & 1 \\
\hline
\end{tabular}

Tablo 16'ya göre en yüksek ilişkinin algılanan fayda ile algılanan kullanım kolaylığı arasında olduğu $(r=, 798)$ en düşük ilişkinin ise gizlilik ile güven arasında olduğu $(0,01)$ görülmektedir.

\section{Tartışma ve Sonuç}

Başlangıçta askeri bir amaç için geliştirilmiş olan internet günümüzde hayatın en önemli bilgi edinme ve paylaşma araçlarından biri haline gelmiştir (Dağtaş ve Yıldırım, 2015, s.149). Öyle ki TÜíK (2018) tarafından son üç ay içinde internet kullanan bireylerin interneti kişisel kullanma amaçları raporu incelendiğinde bireylerin \%80,9'u interneti sosyal medya üzerinde profil oluşturma, $\% 70,2$ 'si online gazete ya da dergi okuma amacıyla kullanırken \%66,2'si sağlıkla ilgili bilgi arama amacıyla kullandığ gözlemlenmiştir. İnternetin sosyal medya üzerinden profil oluşturma, mesaj gönderme, online gazete yada dergi okuma gibi geniş kullanım alanlarının olmasına karşın aynı zamanda önemli bir alışveriş yapma aracı olarak da kullanıldığı literatür taramasından ve alan araştırmasından görülmektedir.

İnternet üzerinden alışveriş diğer bir adıyla online alışveriş (çevrimiçi); son yıllarda bireyler tarafından sıkça tercih edilen bir alışveriş yöntemidir. Özellikle Türkiye'de internet kullanımının giderek yaygınlaşması, kadın ve erkeklerin iş hayatından dolayı yoğun bir hayat sürmeleri, internet üzerinden müşteriler için sunulan kampanyaların fazla olması, yaşam şartlarının git gide zorlaşması gibi nedenler bireyleri online alışverişe yönlendirmektedir. 
Çalışmanın amacı online (çevrimiçi) alışveriş yapan süpermarket tüketicilerinin tüketim tercihlerini etkileyen faktörleri teknoloji kabul modeli ile açıklamaktır. Bu amaç doğrultusunda çalışmada teknoloji kabul modelinin ana değişkenleri olan algılanan fayda, algılanan kullanım kolaylığı, tutum ve niyet değişkenleri ve bu değişkenler üzerinde etkisi olduğu düşünülen güven, gizlilik ve alışveriş keyfi gibi değişkenler arasındaki ilişkiler irdelenmiş ve aşağıdaki sonuçlara ulaşılmiştır.

Güvenin, algılanan fayda üzerinde etkisinin olup olmadığını tespit etmek amacıyla yapılan analizler sonucunda güven ile algılanan fayda arasında pozitif yönlü bir ilişki olduğu tespit edilmiştir. Doğal olarak tüketicilerin online satın almaya duydukları güven arttıkça algıladıkları fayda da artacaktır. Sünnetçioğlu ve Yıldırım (2019), tarafından "Sokak yiyeceklerinin tüketiminde satıcıya olan güven, algılanan risk, algılanan fayda, tutum ve satın alma niyeti arasındaki ilişkilerin incelenmesi" amacıyla yapılan çalışma da benzer sonuçlara ulaşılmıştır.

Güvenin, algılanan kullanım kolaylığı üzerindeki etkisi basit doğrusal regresyon analizi ile test edilmiş ve analiz sonucu istatistiksel olarak anlamlı bulunmuştur. Ancak Pourmousa'nın (2017) e-devlet sistemini kullanan kullanıcıların, kullanma davranışlarını etkileyen faktörleri tespit etmek amacıyla yaptığ çalışmasında güven faktörünün, algılanan kullanım kolaylığı üzerinde etkisi olmadığı görülmektedir. İnsanların edevlet sisteminin güvenli olduğu konusunda emin olmadıklarından dolayı bu ilişkinin anlamsız olduğu düşünülmektedir.

Çalışmada elde edilen sonuçlardan bir diğeri ise; gizliliğin ve alışveriş keyfinin, algılanan fayda ve algılanan kullanım kolaylığı üzerinde etkisi olduğudur. Ancak alışveriş keyfi ile algılanan fayda arasındaki ilişki yüksek ve pozitif yönlü iken, gizlilik ile algılanan fayda arasındaki ilişki düşük düzeyde pozitif yönlüdür.

Algılanan kullanım kolaylığının algılanan fayda üzerinde etkisi basit doğrusal regresyon analizi ile test edilmiş ve analiz sonucu istatistiksel olarak anlamlı bulunmuştur. Bu çalışmada algılanan kullanım kolaylığının algılanan fayda üzerinde etkisi bulunmasına rağmen bazı çalışmalarda algılanan kullanım kolaylığının algılanan fayda üzerinde etkisi olmadığı gözlemlenmiştir. (Hong ve Tam, 2006; Chen ve diğ., 2004; Wu ve diğ., 2007). 
Algılanan faydanın, tutum üzerinde etkisi basit doğrusal regresyon analizi ile test edilmiş ve analiz sonucu istatistiksel olarak anlamlı bulunmuştur. $\mathrm{Bu}$ bulgu sınıf öğretmenlerinin teknoloji kabullerini etkileyen etkenlerin neler olduğunu tespit etmek amaciyla yapılan çalışmada da desteklenmektedir. Diğer bir ifadeyle hem yapılan çalışmada hem de bu konu üzerine yapılan çalışmalarda algılanan faydanın tutumu etkilediği söylenebilir (Turan, 2011, s.59).

Algılanan kullanım kolaylı̆̆ının, tutum üzerindeki etkisi basit doğrusal regresyon analizi ile test edilmiş ve analiz sonucu istatistiksel olarak anlamlı bulunmuştur. Bunun anlamı katılımcıların çevrim içi alı̧̧veriş teknolojisini benimsemelerine yönelik algıladıkları kullanım kolaylığının bu teknolojiyi benimsemelerine yönelik tutumlarını olumlu yönde etkilediğidir. Özcan, Sabah Çelik ve Özer (2019) tarafından Türkiye'deki bireysel bankacılık müşterilerinin mobil bankacılığ kullanım niyetlerini etkileyen faktörlerin analiz edilmesi amacıyla yapılan çalışma sonucunda da benzer sonuçlara ulaşılmıştır.

Tutumun, niyet üzerindeki etkisi basit regresyon analizi ile test edilmiş ve analiz sonucu istatistiksel olarak anlamlı bulunmuştur. Bu bulgu iki farklı ülkede üniversite öğrencilerinin internet üzerinde ürün alımlarının etkileyen faktörlerin teknoloji kabul modeli ile açıklanması amacıyla yapılan çalışma tarafından da desteklenmektedir (Naserınıa, 2019, s.65).

Teknolojiyi kullanmaya açık olan tüketiciler yeni teknolojik ürünleri kullanmaktan çekinmezler. Ancak teknolojiyi kabul etme ve kullanma yönünde geç kalan tüketiciler ise ki literatürde Rogers (1995)'ın yeniliğin yayılması modeli (Demir, 2006, s.369) ile tanımlayabileceğimiz türdeki daha geç uyum gösteren tüketiciler bağdaşma ve güven konusunda problem yaşayabilecektir. Firmalar, bu sinıfta yer alan tüketicilere yönelik online alışverişin kullanımının kolay olduğuna ve yaşamlarını planlamaya yönelik avantaj yarattığına ikna edecekleri tutundurma teknikleri kullanmalıdırlar.

Bu çalışmanın sonuçlarından yola çıkarak, online alışveriş sitelerinde ürün satan firmalar işlerinde daha başarılı olmak için, tüketicilerin süpermarket sitelerinde sunulan ürünleri satın alma sırasında tutum ve niyetlerini etkileyen faktörleri iyi bir şeklide bilmeleri gerekmektedir. Ayrıca, üst yöneticiler daha fazla müşteri çekmek, e-ticaret olanaklarını 
kullanarak daha fazla kar elde etmek ve daha fazla rekabet avantaj1 sağlamak için pazarlama stratejilerini bu faktörleri dikkate alarak şekillendirmeleri gerekmektedir. Araştırma sonuçları dikkate alındığında müşterilerin ödeme seçeneklerinde sanal kartı büyük çoğunlukla kullanmamasının nedenleri firmalar tarafından araştırılabilir ve tüketiciler bu konu hakkında bilgilendirilebilir.

Çalışmada elde edilen sonuç, online alışveriş davranışı üzerinde etkisi bulunan güvenin, gizliliğin, alışveriş keyfinin; algılanan fayda ve kullanım kolaylığı üzerine olumlu etkilerinin olmasıdır. Dolayısıyla, satın alma eğilimi üzerinde önemli etkileri saptanan, algılanan fayda ve kullanım kolaylığını etkileyen her türlü değişken, yöneticilerin firmaları için fırsata dönüştürebilecekleri birer değişkendir. $\mathrm{Bu}$ nedenle, yöneticiler, güven gizlilik ve alışveriş keyfini etkileyen unsurları saptayarak tüketicileri online alışverişe yönlendirebilir ve satışlarını arttırabilirler. Online alışveriş hizmeti sunan işletmeler, bu alanda henüz reklam ağını genişletmemişlerdir. Bu nedenle, reklam ağlarını genişletip daha sık reklam yaptıklarında daha fazla gelir elde edebileceklerdir.

Online alışverişin daha kolay olması ve zahmet gerektirmemesi tüketicilerin online olarak alışveriş yapmasında etkilidir. Bu yüzden firmalar tarafından geliştirilen alışveriş sitelerinin kullanımının kolay ve anlaşılabilir olması sağlanmalıdır. Tüketicinin aradığı ürünü kolaylıkla bulabileceği bir web tasarımı geliştirilmelidir. Ayrıca, bu sitelerin gelişen teknolojiye ve sektörel gelişime ayak uydurup düzenli olarak güncellenmesi faydalı olacaktır.

Çalışmada veriler, belirli illerde yaşayan süpermarketlerde online alışveriş yapan tüketiciler üzerinden toplanmıştır. Bu durum çalışmanın kısıtları arasında yer almaktadır. Bu kısıttan hareketle çalışma, farklı illerde daha büyük örneklemler ile gerçekleştirilebilir. Çalışmada Davis' in orijinal TAM modeline sadık kalınmıştır. Gelecekte yapılacak çalışmalarda modele farklı değişkenler (öznel norm, dışsal değişkenler vb.) eklenerek konu farklı bir bakış açısı ile daha da zenginleştirilebilir. Çalışmada algılanan fayda ve algılanan kullanım kolaylığı üzerinde etkisi olduğu düşünülen güven, gizlilik, alışveriş keyfi gibi faktörler dışında başka faktörlerinde etkisinin olup olmadığı araştırılabilir. 


\title{
EXTENDED ABSTRACT
}

\section{Explanation of the Consumption Preferences of Supermarket Consumers Making Online Shopping with Technology Acceptance Model \\ *}

\author{
Perihan Işık- Murat Öz \\ Nevşehir Hacıbektaşı Veli University- Karamanoğlu Mehmeetbey University
}

The internet has become a part of our lives along with the developing world. Consumers and businesses use the internet for different purposes. For example, while businesses use the internet to carry out marketing activities, consumers use it for shopping. Thanks to the internet, businesses can communicate with customers and reach customers easily by eliminating geographical borders.

There are many positive and negative factors that have an impact on consumers' online shopping behavior. These factors are privacy, security and trust, saving time, ease of use and shopping pleasure.

Privacy refers to something that should remain latent or kept secret (Aslanyürek, 2016, p.84). The most important factor that prevents an individual from shopping online is the distrust of the website regarding the storage of information and the problem of distrust arising from the possibility of misuse of information (Eastlick, Lotz, \& Warrington, 2006, p.877). Most of the time, users have to share some personal information with the website while shopping online. In this case, the privacy rules that ensure trust in commercial websites are important to positively change the consumer's intention (Elhassan, 2016, p.15).

Security refers to protecting information availability, integrity, and confidentiality (Yağcl, El-Hassan \& Doğrul, 2017, p.114). Meanwhile, trust refers to keeping the promise made by the seller to the consumer and delivering the product and service ordered by the consumer at the specified time (Aksoy and Sever, 2012, p.155).

Online shopping is a good alternative for consumers who do not want to spend most of their time in the store and preferred by many consumers as it provides time savings (Uslu, 2018, p.61). Online 
shopping allows consumers to easily buy products at any time of the day without wasting time (Yıldırım, 2017, p.28).

Information technologies, which are an indispensable element of our day, take place in every aspect of our lives. While information technologies were accepted instantaneously in some sectors, they encountered resistance in some sectors and took time to spread (Kaş, 2015, p.37). Although information technologies provide significant cost savings and service increase, it is important to know why individuals do not prefer these technologies (Turan and Özgen, 2009, p.135). In this context, the following questions are important (Özer, Özcan, \& Aktaş, 2010, p.3279);

- Why do users accept or reject the technology offered?

- What are the reasons for their behavior?

- If users have accepted and are using information technologies, what are the reasons behind this? Will users continue to use information technology in the future?

In order to answer all these questions, the "Intention Models" that reveal how technology acceptance occurs suggested (Kaş, 2015, p.37). Intention models calculate the benefits that the behavior exhibited by individuals will bring to them. Thus, it helps to estimate the effect of attitudes that accept that they decide among many alternatives on behaviors (Kahya, 2015, p.48). One of the mentioned model is the Technology Acceptance Model (TAM) (Türker, 2013, p.286). TAM aims to predict users' resistance to new technologies, the underlying reasons for technology acceptance, and finally, to predict users' responses to new technologies, and to reveal the development in real use with the change in the system. TAM was developed by Davis in 1986 (Çelik and İp̧ioğlu, 2006, p.113). The aim of the model is to explain the adaptation factors that can be generalized to many technological innovations and applied to their use (Zeren, 2014, p.171).

TAM measures technology acceptance by basing it on four main factors: perceived usefulness, perceived ease of use, attitude, and intention. Perceived usefulness is the positive perception of people that their performance will increase by using a certain technology (Kalyoncuoğlu, 2018, p.196). Perceived ease of use is the belief that an individual will not spend effort while using any system (Bağlibel, 
Samancioğlu, \& Summak 2010, p.334). Tttitude is positive or negative feelings regarding using technology, willingness or unwillingness of using technology, or being against or for using technology (Akça ve Özer, 2012, s.82). Behavioral intention is an indicator of an individual's readiness to exhibit the behavior or how willing the individual is to perform the behavior (Akıncı \& Kıymalığlu, 2014, p.395).

The aim of this study is to explain the factors affecting the consumption preferences of online supermarket consumers with TAM. For this purpose, the relationships between the main variables of TAM, such as perceived usefulness, perceived ease of use, attitude and intention, and variables such as trust, privacy, and shopping pleasure, which are thought to have an effect on these variables, were examined.

In the study, data were obtained through a questionnaire. The questionnaire was applied to supermarket consumers who shopped online at least once from supermarkets with the purposive sampling method. A total of 604 people were surveyed. The collected data were analyzed with the SPSS 21 package program. Descriptive statistical analysis of the demographic characteristics of the sample was applied. Explanatory factor analysis was used to determine the construct validity of the scale, and Cronbach's Alpha coefficients were calculated to test the internal consistency of the scale statements. The decision regarding the tests to be used during the analysis is made according to the normal distribution of the data. For this reason, the data were tested for normality, and the kurtosis and skewness coefficients were examined. Correlation analysis was performed to determine whether there is a relationship between the variables and, if there is, the direction of it. Simple linear regression analysis was used to determine the explanatory power of one variable for another variable, and correlation analysis was used to determine the direction and strength of the relationship. The result indicates that trust, privacy and shopping pleasure have an effect on the perceived usefulness, perceived ease of use, attitude, and intention, which are the main variables of TAM.

\section{Kaynakça / References}

Agcadağ, İ. (2014). Sanal alışveriş. Mediterranean Journal of Humanities, 4(1), 21-33. 
Akbaba, A.İ. (2018). Dördüncü endüstri devrimine geçiş sürecinde üç boyutlu yazıcı kullanımının teknoloji kabul modeliyle ölçümlenmesi: Otomotiv endüstrisinde bir araştırma. Doktora Tezi. Atatürk Üniversitesi, Erzurum.

Akça, Y. ve Özer, G. (2012). Teknoloji Kabul Modeli'nin kurumsal kaynak planlaması uygulamalarında kullanılması. Business and Economics Research Journal, 3(2), 79-96.

Paçan Özcan, H, Sabah Çelik, Ş, ve Özer, A. (2019). Bireysel müşterilerin mobil bankacılık kullanım niyetini etkileyen faktörler. Çankırı Karatekin Üniversitesi İktisadi ve İdari Bilimler Fakültesi Dergisi, 9(2), 475-506.

Akıncı, S. ve Kıymalığlu, A. (2014). Pazarlama teorileri. Mehmet İsmail Yağcl, Serap Cabuk (editör) Gerekçeli Eylem Teorisi (297-310). İstanbul.

Dağtaş, E. ve Yıldırım, O. (2015). İnternet ve sosyal ağlar dolayımlı gündelik yaşam pratikleri: Anadolu Üniversitesi Öğrencileri üzerine mikro alan araştırmasi. folklor/edebiyat, 21(83), 149-180.

Akman, E. ve Işık, M. (2018). Kamu Çalışanlarında internetsiz kalma korkusu (Netlessfobi): Isparta ilinde bir araştırma. Avrasya Uluslararası Araştırmalar Dergisi, 6(14), 20- 37.

Aksoy, R. ve Sever, H. (2012). Elektronik pazarlarlarda güven problemi ve kriminal faaliyetler. Electronic Journal of Vocational Colleges, 2(1), 154164.

Aktaş, S. (2007). Teknoloji kabul modeli ile muhasebecilerin bilgi teknolojisi kullanımına yönelik bir uygulama. (Yayınlanmamış Yüksek Lisans Tezi). Gebze Yüksek Teknoloji Enstitüsü, Sosyal Bilimler Enstitüsü, Kocaeli.

Aslanyürek, M. (2016). İnternet ve sosyal medya kullanıcılarının internet güvenliği ve çevrimiçi gizlilik ile ilgili kanaatleri ve farkındalıkları. İletişim Fakültesi Dergisi, 3(1), 80-106.

Atik, E. (2015). Turizmde akıll telefon kullanımınin Teknoloji Kabul Modeli kapsamında değerlendirilmesi. Anadolu Üniversitesi Sosyal Bilimler Enstitüsü, Eskişehir.

Bağlıbel, M. Samancıoğlu M. ve Summak M. S. (2010). Okul yöneticileri tarafından E-Okul uygulamasının genişletilmiş teknoloji kabul modeline göre değerlendirilmesi. Mustafa Kemal Üniversitesi Sosyal Bilimler Enstitüsü Dergisi, 7(13), 331-348. 
Başgöze, P. (2010). Teknoloji kabul modelinin teknolojik yatkınlık ve marka kredibilitesi değiş̧kenleri eklenerek genişletilmesi: Satın alma eğilimine uyarlanma. (Doktora Tezi). Hacettepe Üniversitesi Ankara.

Çakır, C.B. (2009). İnternet üzerinden satın alma davranışının incelenmesi ve bir uygulama. (Yayınlanmamış Yüksek Lisans Tezi). İstanbul Teknik Üniversitesi Fen Bilimleri Enstitüsü, İstanbul.

Çelik, H. ve İpçioğlu, İ. (2006). Gönüllü teknoloji kabulü: İnternet kullanımını benimseme davranışı üzerine bir araştırma. H.Ü. İktisadi Ve İdari Bilimler Fakültesi Dergisi, 24(1), 111-139.

Çelik, C.H., ve Bindak, R. (2005). İlköğretim okullarında görev yapan öğretmenlerin bilgisayara yönelik tutumlarının çeşitli değişkenlere göre incelenmesi. Eğitim Fakültesi Dergisi, 6(10), 27-38.

Çetinsöz, B.C. (2015). Yerli turistlerin e-satın alma eğilimlerinin Teknoloji Kabul Modelinde analizi (TKM). Elektronik Sosyal Bilimler Dergisi, 14(53), 242-258.

Davis, F. D., Bagozzi, R. P. and Warshaw, P. R. (1989). User Acceptance of computertechnology: A comparison of two theoretical models. Management Science, 35(8), 982-1003.

Demir, K. (2006). Rogers' in Yeniliğin Yayılması Teorisi ve internetten ders kaydı. Kuram ve Uygulamada Ĕ̆itim Yönetimi, 47, 367-392.

Dikkaya, M. ve Aytekin, İ. (2019). Bilgi iletişim teknolojileri ve dijital ekonomi: Avrupa Birliği ve Türkiye arasında bir karşlaştırma. Üçüncü Sektör Sosyal Ekonomi Dergisi, 54(3), 1279-1299.

Durmuş, B., Yurtkoru, S. E. ve Çinko, M. (2013). Sosyal bilimlerde SPSS'le veri analizi. İstanbul: Beta Yayınları.

Dursun, F. (2004). Üniversite öğrencilerinin interneti kullanma amaçları. XIII. Ulusal Eğitim Bilimleri Kurultayı, 6-9 Temmuz 2004 İnönü Üniversitesi, Eğitim Fakültesi, Malatya.

Eastlick, M. A., Lotz, S. L. and Warrington, P. (2006). Understanding Online B-toCRelationships: An integrated Model of privacy concerns, trust, and commitment. Journal of Business Research, 59(8), 877-886.

El-Hassan, M. (2016). Hizmet sektöründe online alışveriş davranışını etkileyen faktörler: Seyahat sektörü (Türkiye ve Slovenya karşılaştırmasl). Yayınlanmamış Yüksek Lisans Tezi. Mersin Üniversitesi Sosyal Bilimler Enstitüsü, Mersin.

Enginkaya, E. (2006). Elektronik perakendecilik ve elektronik alışveriş. Ege Akademik Bakış Dergisi, 6(1), 10-16. 
Erkmen, Y. (2009). Bankacllk Sektöründe teknolojik hizmetlerin müşteriler tarafindan benimsenmesinde etkili faktörler. (Yüksek Lisans Tezi). İstanbul Teknik Üniversitesi, İstanbul.

Ersoy, E. (2016). Tüketicilerin değişen alışveriş alışkanlıkları (Onlıne alışveriş). İletişim Çalışmaları Dergisi, 3(4), 87-129.

Gül, H. ve Boz, M. (2012). İnternet Ortaminda pazarlama, online rezervasyon; Şehirlerarası otobüs firmaları üzerine bir araştırma. BAP Proje No: 2011/88, 1- 30.

Gümüşsoy, Ç.A. (2009). Elektronik-Açık eksiltme teknolojisinin kullanımın etkileyen faktörlerin genişletilmiş teknoloji kabul modeli ile açıklanması. (Yayınlanmamış Doktora Tezi). İstanbul Teknik Üniversitesi, İstanbul.

Hong, S., and Tam, K.Y., 2006. Understanding the adoption of multipurpose information appliances: The case of mobile data services. Information Systems Research, 17(2), 162-179.

İzci, B.B. ve Şahin, İ. (2013). Elektronik perakende sektörü ve internet alışverişi tüketici davranışı: Türkiye örneği. Ekonomi ve Yönetim Araştırmaları Dergisi, 2(1), 9-27.

Kahya, V. (2015). Insan kaynaklarn bilgi sistemlerinin kullanımında etkili olan faktörlerin genişletilmiş teknoloji kabul modeli ile incelenmesi. (Yayınlanmamış Doktora Tezi). Dumlupınar Üniversitesi Sosyal Bilimler Enstitüsü, Kütahya.

Kalyoncuoğlu, S. (2018). Tüketicilerin online alışverişlerindeki sanal kart kullanımlarının teknoloji kabul modeli ile incelenmesi. Afyon Kocatepe Üniversitesi Sosyal Bilimler Dergisi, 20(2), 193-213.

Kaş, E. (2015). Otel rezervasyon siteleri üzerinden yapılan online alışverişin teknoloji kabul modeliyle incelenmesi. (Yayınlanmamış Yüksek Lisans Tezi). Balıkesir Üniversitesi Sosyal Bilimler Enstitüsü, Balıkesir.

Kırcova İ. (2012). İnternette pazarlama. İstanbul: Beta Yayınları.

Nakip, M. ve Yaraş, E. (2017). SPSS uygulamal pazarlamada araştırma teknikleri (5. Basım). Ankara: Seçkin Yayıncıllk.

Naserını, M. (2019). Farklı kültürlerdeki üniversite öğrencilerinin internet üzerinden ürün alıslarının teknoloji kabul modeli ile incelenmesi. (Yayınlanmamış Yüksek Lisans Tezi). Atatürk Üniversitesi Sosyal Bilimler Enstitüsü, Erzurum. 
Nazir, S., Tayyab, A., Sajid, A., Rashid, H. and Javed, I. (2012). How online shopping is affecting consumers buying behavior in Pakistan. International Journal of Computer Science, 9(3), 486-495.

Özer, G., Özcan, M., ve Aktaş, S. (2010). Muhasebecilerin bilgi teknolojisi kullanımının Teknoloji Kabul Modeli (TKM) ile incelenmesi. Journal Of Yaşar University, 5(19),3278 - 3293.

Özgüven, N. (2011). Tüketicilerin online alışverişe karşı tutumları ile demografik özellikleri arasındaki ilişkinin analizi. KMÜ Sosyal ve Ekonomık Araştırmalar Dergisi, 13 (21), 47-54.

Pazvant, E. (2017). Nesnelerin interneti teknolojisine sahip ürünlerin kullanım niyetinin teknoloji kabul modeli kapsamında değerlendirilmesi. (Yüksek Lisans Tezi). Düzce Üniversitesi, Düzce.

Pourmousa, H. (2017). E-Devlet sisteminin kullanımında etkili olan faktörlerin teknoloji kabul modeli ile incelenmesi. (Yüksek Lisans Tezi). Atatük Üniversitesi, Erzurum.

Sünnetçioğlu, S. ve Yıldırım, H.M. (2019). Sokak yiyeceklerinin tüketiminde satıcıya olan güven, algılanan risk, algılanan fayda, tutum ve satın alma niyeti arasındaki ilişkilerin incelenmesi. Manas Sosyal Araştırmalar Dergisi, 8(3), 2799-2818.

Tarı Cömert I. ve Kayıran S.M. (2010). Çocuk ve ergenlerde internet kullanımı. Çocuk Dergisi, 10(4), 166-170.

Tekeli, S., ve Şahin, A. (2018). Tüketicilerin akıllı telefon uygulamalarını kullanma niyetini etkileyen faktörlerin kullanım tutumuna ve niyetine etkisi. Toros Üniversitesi İktisadi İdari ve Sosyal Bilimler Fakültesi Dergisi, 5(8), 178-197.

Tepe, M.E. (2018). Tesettür moda reklamlarında ikna bilgi modelinin kullanımı: $Y$ kuşağına yönelik bir uygulama. (Doktora Tezi). Karamanoğlu Mehmetbey Üniversitesi, Karaman.

Turan, A.H. (2008). İnternet alışverişi tüketici davranışını belirleyen etmenler: Geliştirilmiş teknoloji kabul modeli (E-TAM) ile bir model önerisi. Akademik Bilişim Konferansı, (30 Ocak - 01 Şubat), 723-731.

Turan, A.H. (2011). İnternet Alışverişi tüketici davranışını belirleyen etmenler: Planlı Davranış Teorisi (TPB) ile ampirik bir test. Doğuş Üniversitesi Dergisi, 12(1), 128-143

Turan, A.H. ve Özgen, F. B. (2009). Türkiye'de E-Beyanname sisteminin benimsenmesi: Geliştirilmiş Teknoloji Kabul Modeli ile ampirik bir çalışma. Doğuş Üniversitesi Dergisi, 10(1), 134-147. 
Turan, B. (2011). Bilgi ve iletişim teknolojileri kullanımının teknoloji kabul modeli ile incelenmesi ve sinıf öğretmenleri üzerinde bir uygulama. Bilecik Üniversitesi Sosyal Bilimler Enstitüsü, Bilecik.

Turan, H. (2017). Tüketici yenilikçiliği ve internetten alışveriş: Kayseri'de bir uygulama. Yayınlanmamış Yüksek Lisans Tezi. Nuh Naci Yazgan Üniversitesi Sosyal Bilimler Enstitüsü, Kayseri.

Türker, A.ve Türker, G.O. (2013). Turistik ürün satın alma davranışının teknoloji kabul modeli ile incelenmesi. Sosyal Bilimler Enstitüsü Dergisi, 15(2), 281-312.

Uslu, H. (2018) Muhafazakâr kadınların online alı̧̧eriş yapma davranışları üzerine bir alan araştırması. (Yayınlanmamış Yüksek Lisans Tezi). Selçuk Üniversitesi Sosyal Bilimleri Enstitüsü, Konya.

Uygun, M, Özçifçi, V. ve Divanoğlu, S. (2011). Tüketicilerin online alışveriş davranışını etkileyen faktörler. Organizasyon ve Yönetim Bilimleri Dergisi, 3(2), 373-385.

Uzel, E., ve Aydoğdu, F.C. (2010). Çalışanların elektronik alışverişe bakış açıları hakkında kalitatif calışma. Organizasyon ve Yönetim Bilimleri Dergisi, 2(1), 19-25.

Vijayasarathy, L. R. (2004). Predicting consumer intentions to use on-line shopping: The Case for an augmented technology acceptance model. Information \& Management, 41(6), 747-762.

Yağcl, M.İ., El- Hassan, M. ve Doğrul, U. (2017). Tüketicilerin online alışverişe karşı tutumlarını ve online alı̧̧veriş yapma niyetlerini etkileyen faktörler: Türkiye- Slovenya karşılaştırması. Siyaset, Ekonomi Ve Yönetim Araştırmaları Dergisi, 5(5), 111-123.

Yıldırım, L. (2017). Online alı̧̧eriş sitelerinde uygulanan canlı destek sistemlerinin tüketicilerde oluşturduğu güvene etkisi: Bir araştırma. (Doktora Tezi). Adnan Menderes Üniversitesi Sosyal Bilimler Enstitüsü, Aydın.

Yılmaz, C. (2010). Online alş̧verişte algılanan değer, memnuniyet, güven ve sadakat arasındaki ilişki. (Yayınlanmamış Yüksek Lisans Tezi). Cumhuriyet Üniversitesi Sosyal Bilimler Enstitüsü, Sivas.

Yılmaz, Ö. (2018). Tüketicilerin online alışveriş niyetlerinin teknoloji kabul modeli bağlamında incelenmesi. Afyon Kocatepe Üniversitesi Sosyal Bilimler Dergisi, 20(3), 331-346. 
Yılmaz, V., Arı, E. ve Doğan, R. (2016). Online alışverişte müşteri şikâyet niyetleri ve davranışlarının yapısal eşitlik modeli ile incelenmesi. Journal of Yasar University, 11(42), 102-112.

Erdem, H. K. (2011). Kurumsal kaynak planlama sistemlerinin kullanımında etkili olan faktörlerin genişletilmiş teknoloji kabul modeli ile incelenmesi. (Doktora Tezi). İstanbul Teknik Üniversitesi Fen Bilimleri Enstitüsü, İstanbul.

Zeren, D. (2014). Pazarlama teorileri. Mehmet İsmail Yağcl, Serap Çabuk (editör) Gerekçeli Eylem Teorisi (297-310). İstanbul.

\section{Kaynakça Bilgisi / Citation Information}

Işık, P. ve Öz, M. (2021). Online alışveriş yapan süpermarket tüketicilerinin tüketim tercihlerinin Teknoloji Kabul Modeliyle açıklanması. OPUS-Uluslararası Toplum Araştırmaları Dergisi, 18(Yönetim ve Organizasyon Özel Sayıs1), 1538-1572. DOI: 10.26466/opus.837561. 